\title{
Biodiversity and the Corporate Social Responsibility Agenda
}

\author{
Greet Overbeek ${ }^{1}$, Bette Harms ${ }^{1} \&$ Sander Van den Burg ${ }^{1}$ \\ ${ }^{1}$ LEI Wageningen University and Research Centre, The Hague, the Netherlands \\ Correspondence: Greet Overbeek, LEI Wageningen University and Research Centre, The Hague, the \\ Netherlands. E-mail: greet.overbeek@wur.nl
}

Received: July 1, 2013 Accepted: July 22, 2013 Online Published: August 2, 2013

doi:10.5539/jsd.v6n9p1 URL: http://dx.doi.org/10.5539/jsd.v6n9p1

\begin{abstract}
In this paper, we describe the main findings of an exploratory research about corporate commitment to manage biodiversity and ecosystems. The results are based on literature of sustainability approaches and interviews with sustainability representatives of twelve national and international companies in the Netherlands. The empirical results show that companies still use a reactive approach to biodiversity. Biodiversity is getting more attention on the sustainability agenda of the executive board. While external networking with stakeholders is increasing, both in networks and partnerships, creating internal commitment for the corporate responsibility on biodiversity and ecosystems remains challenging.
\end{abstract}

Keywords: biodiversity, Corporate Social Responsibility (CSR) approaches, businesses, stakeholders

\section{Introduction}

The loss of biodiversity is one of the pressing twenty-first century issues that calls for action. Biodiversity supports the world we live in and its intrinsic value, focusing on the wealth of species and habitats, and is often communicated globally in the media and public policy (for example the Convention on Biological Diversity (CBD, 1992)). However, its value is still intangible for people who might adjust their activities to protect the environment. Therefore, to an increasing extent the extrinsic value is now communicated by focusing on the services ecosystems provide to human societies. Ecosystems are defined as biotic and abiotic natural resources and their interactions whose functions, such as provision of food and water and regulation of climate control, result in various services and benefits for people (Millennium Ecosystem Assessment, 2003).

Until now, most of the communication about the extrinsic value of biodiversity in relation to ecosystem services focuses on the economic valuation of their ecological functions in terms of costs and benefits that may interest public policy makers. Studies of The Economics of Ecosystems and Biodiversity (TEEB) have resulted in general reports (TEEB, 2010a) and specific reports, among others for businesses (TEEB, 2010b). However, the underlying assumptions of rational economic agents, well-functioning markets, consistent preference etc. need attention if the value is to be comprehensive, acceptable and feasible not only for behavioural scientists and public policy makers, but even more so for businesses and citizens. The behavioural underpinnings of rational choices and resource allocation are hardly acknowledged, nor is the co-evolutionary nature of people and ecosystems (Kumar \& Kumar, 2008).

To explore the co-evolution between environmental sustainability transitions and shifts within businesses, it should be noted that transitions go through a long predevelopment phase. Transitions are major, non-linear changes in the regime with its dominant societal cultures, structures and practises. In the long predevelopment phase there is a gradual build-up of pressure on the regime, which stems from an internal dysfunction, increasing competition of alternatives, or a changing external context (Loorbach \& Wijsman, 2013). In the context of environmental sustainability, transitions seem inevitable from the perspective of limited resources, ecological thresholds (Rockstrom et al., 2009) and changing economic and demographic landscapes.

Furthermore, since many local activities to manage biodiversity and ecosystems have a global impact, improvements are difficult to organise. While poor countries are encouraged to produce natural resource-intensive primary commodities such as timber or fish, rich countries in the Western world produce capital-intensive products by using the resources of developing countries (Gale, 2000). Many Western companies depend on ecosystems, for the continuity of raw material supplies elsewhere in the world and for the use of regulatory services. They may also have a global impact on biodiversity, positively or negatively. The 
negative impact has been often described through the transformation of natural areas into production areas (deforestation) or into industrial sites; the pollution of water, air and soil resulting from economic activities and the capture of animals for food like fishing.

When companies began addressing environmental issues themselves, it was usually in terms of risks or costs, and their license to operate (Kolk \& Van Tulder, 2010). This included a role in the protection of biodiversity in those cases were public policies required them to do so, for example through the Natura 2000 regulation. However, it is argued that they are becoming aware of the advantages sustainability has to offer (Porter \& Kramer, 2006). Often driven by ambitious CEOs and other executives, several businesses are trying to move beyond traditional Corporate Social Responsibility (CSR) and environmental reporting to shape and transform the value chains and markets they operate in along with their company's internal organisation (Loorbach et al., 2010). Businesses are searching for ways to deal with such unpredictable changes, especially in sectors like food, energy and mobility where major societal changes are expected to occur in the coming decades. In this debate, it is often argued that businesses should be involved in the protection of biodiversity and ecosystem services (TEEB, 2010b; PWC, 2010; KPMG, 2011).

In this paper we explore the predevelopment phase of environmental sustainability transitions and shifts within businesses by analysing their perspective on the importance of biodiversity. Our focus will be on environmental transitions within Netherlands-based companies that would like to engage their business in a sustainable way with biodiversity and natural resources. In general, it is argued that various types of strategic behaviour can be witnessed in such shaping contexts, ranging from reactive to active (cf. Van Tulder \& Van der Zwart, 2006). Therefore several CSR approaches will be outlined and will be related to the influence of their stakeholders. Afterwards, we will present the results from the interviews with sustainability representatives from companies whose production processes depend on the continuity of natural resources or are considered to have an impact on biodiversity. Finally, we discuss some possibilities to increase the involvement of companies to manage biodiversity and ecosystems.

\section{Corporate Social Responsibility Approaches and Stakeholders}

\subsection{CSR Approaches}

Usually, approaches to CSR can be considered a response to two strategic tensions (cf. Van Tulder with Van der Zwart, 2006) or interdependencies (Porter \& Kramer, 2006) firms generally face in their: 1) intrinsic moral attitude between 'liability' and 'responsibility' (internal alignment) and 2) extrinsic responsiveness towards stakeholders between an 'inward looking' and an 'outward looking' perspective (external alignment). They result in four CSR approaches: inactive, reactive, active and pro-active (Van Tulder et al., 2009). The inactive approach is an inward-looking business perspective, without stakeholder involvement aimed at efficiency and competitiveness in the immediate market environment, while the reactive approach is a liability orientation where entrepreneurs manage their external stakeholders expectations by decreasing their environmental impact without fundamental changes in the business philosophy and primary production processes. The active approach represents entrepreneurs who are subsequently inward looking to realise their objectives in a socially responsible manner regardless of actual or potential social pressures by external stakeholders, while in a pro-active approach an entrepreneur undertakes activities aimed at external stakeholders right at the beginning of an issue's life cycle within a socially responsible manner.

Although CSR approaches are far from smooth one-dimensional trajectories, the suggestion is that companies may develop from a reactive to an active approach and thus towards new internal and external alignment with its stakeholders. Firms become activated towards more explicit CSR strategies because they are stimulated by critical consumers, outspoken Non-Governmental Organisations (NGOs) or the threat of regulation by governments. When they are continuously faced with the need to respond to external pressure, they may become less defensive and more active by developing their own internal standards and practices. By identifying sustainability issues at societal level that relate to the firms, they are able to redefine their own products and services and to restructure their own practises and organisation and to opt for an active strategy (Loorbach et al., 2010).

\subsection{Stakeholders}

The CSR approaches of businesses are influenced by several types of stakeholders. While internal stakeholders engage in economic exchanges with the business, external stakeholders, both primary and secondary, can play an important role in the extrinsic responsiveness of businesses. The interaction of primary stakeholders (suppliers, trade-unions, governments, creditors, shareholders etc.), takes up a more strategic dimension and is more or less permanent. In particular the role of suppliers in the value chains of companies may become relevant in the 
transition towards more pro-active forms of CSR and the management approaches at an operational level. In many value chains, a far-reaching division of work is created with different companies undertaking different activities to make a product out of a commodity (Quinn, 1997). Many Western companies act as 'lead firm', steering other firms in the chain, and could be addressed about their good and bad sustainability performances (Lim \& Phillips, 2008; De Tienne \& Lewis, 2005). Whether lead firms are able to engage their suppliers in their CSR strategy, for example with regard to biodiversity protection, is dependent on their value-chain characteristics, in particular the complexity of transactions, the possibility to codify requirements, and the capacity of suppliers (Gereffi, 2005).

Secondary stakeholders, in particular NGOs on environment, create a more indirect bargaining challenge to the organisation. NGOs can damage the reputation of companies that do not contribute to sustainability (Jonker \& Nijhof, 2006), but they may strengthen a reputation if a company contributes to the preservation of biodiversity and natural resources (Van Huijstee, 2010). Furthermore, external cooperation and discussion may increase an organisation's responsiveness to environmental developments. International environmental NGOs with a network in the Netherlands are working with companies to influence the use of raw materials. The World Wildlife Fund (WWF) has identified 35 geographical areas to improve biodiversity, especially for combating deforestation and transforming nature in agricultural areas, and the commodities that are the biggest threat to this (such as soy, palm oil, timber and fish). Based on this analysis, the Dutch WWF branch identified the most relevant lead firms in the Netherlands with whom they aim to develop a partnership for the preservation of biodiversity (www.wwf.nl). The Dutch National Committee of the International Union for the Conservation of Nature (IUCN $\mathrm{NL}$ ) has expertise on how biodiversity and ecosystems can be incorporated into business processes (www.iucn.nl). In the Netherlands IUCN has a business engagement network of 20 international companies. Both organisations have sister networks with NGOs in countries where many commodities are won and have been involved in the development of certification schemes for sustainable production and initiatives (Vermeulen et al., 2011; Schouten \& Glasbergen, 2011).

\section{Methodology}

In the literature most attention goes to CSR policies in general, with relatively little attention given to environmental sustainability transitions and the management of biodiversity. Furthermore, in the case of biodiversity and ecosystem services, attention has mainly been given to the global context, but less has been written about how companies manage these issues in their own business activities. Therefore we have analysed the role of biodiversity empirically in the CSR approaches of companies. In total twelve companies were selected for an interview (Table 1). They were selected because the relationship between their business activities and biodiversity and ecosystems is on their agenda. We identified them because they (i) cooperate with civil society in nature conservation, (ii) participated in the Taskforce Biodiversity and Natural Resources (2011) and/or (iii) are active in formulating Codes of Conduct, relevant for biodiversity conservation (e.g. in the Round Table on Sustainable Soy and Aquaculture Stewardship Council). The information about these activities was collected through corporate websites, projects and products of companies (e.g. annual reports) in which the corporate relationship with biodiversity has been elaborated.

Seven companies operate within an international production chain and are very large in terms of the number of employees (Ahold, DSM, Friesland Campina, Heineken, Ikea, KLM \& Shell). Four companies are small and medium-sized enterprises (Anova, Biohorma, Cono \& De Traay). The remaining company is a large enterprise operating in Western Europe (Eneco). The companies are not selected because of their sustainability performance as a forerunner and there is no account of the extent in which these companies already belong to one of the aforementioned CSR approaches. Hence, in terms of transition management we did not select particular niches experimenting with biodiversity in their business case. Most of the companies are regime players and 'lead' firms in their sectors.

Additional interviews were held with representatives of two NGO's, working in the field of business and biodiversity (WWF \& IUCN NL) to gain insight into civil society perspectives on the role business can and should play. 
Table 1. Selected sectors and companies

\begin{tabular}{ll}
\hline Sectors & \multicolumn{1}{c}{ Companies } \\
\hline Cosmetic industry & - Biohorma specialises in natural medicines and works in the OTC (over the counter) \\
& medicines industry in the Benelux (A. Vogel products). \\
\hline Energy \& & - DSM is an international materials sciences \& life sciences company supplying to other \\
chemistry & companies. \\
- & Eneco manufactures and delivers energy products in Belgium, Germany, the \\
& Netherlands and the United Kingdom. \\
- & Shell is an international energy and petrochemical company working in many \\
& countries. \\
\hline Retail & Ahold is an international group of supermarket and shopping formulas in Europe and \\
& the United States. In the Netherlands it includes formulas of Albert Heijn, Etos and \\
& Gall \& Gall. \\
- & IKEA is an international company of Swedish origin. IKEA offers furniture and living \\
& articles to consumers and covers a large part of the chain of the products it sells. \\
\hline Transport & KLM is an international airline company and part of Air France. \\
\hline Food Industry & - Anova is a trade company that imports fish from Tanzania, Vietnam and Indonesia for \\
& deliverance to retail companies in Europe. \\
- & Cono Kaasmakers is a Dutch dairy co-operative that processes milk from farmers in \\
& the Netherlands to dairy products mainly sold in the Netherlands. \\
- & De Traay Products is a biodynamic honey processor that delivers on supermarkets and \\
& industry. \\
- & FrieslandCampina is an international dairy co-operative that processes milk from \\
& farmers in the Netherlands to dairy products in Europe and worldwide. \\
- & Heineken is the third volume beer brewer in the world. \\
\hline
\end{tabular}

Source: compiled by the authors.

To explore the contribution of national and international companies to manage biodiversity and ecosystems, we will analyse their CSR policy, the business activities that are included to manage the protection of nature and biodiversity and the expected role of those issues in the future (Overbeek et al., 2012). To analyse the role of biodiversity empirically, semi-structured interviews have been held with twelve sustainability managers and directors of the selected companies. The following five main questions have been used as a guideline for the interviews of approximately one and a half hour:

(1) Which CSR approaches do businesses apply (see 4.1)?

(2) To which extent do they pay attention to biodiversity (see 4.2)?

(3) Which activities do businesses undertake to protect biodiversity (see 4.3)?

(4) How do they contribute to biodiversity protection in their value chain management (see 4.4) and

(5) Which obstacles do business foresee to take biodiversity protection a step further (see 4.5)?

We have analysed the qualitative interviews using interpretation and categorization. First, we analysed single interviews, interpreting and summarizing respondents answers to the questions formulated above. In a second step, we compared the results of the different interviews to categorize corporate answers to questions on how the companies include biodiversity issues on their CSR agenda.

\section{Results}

The results show that companies are attempting to include biodiversity in their CSR policy. Biodiversity is a difficult issue for business, it is intangible and not easy to catch in a single indicator. There are few concrete examples of what business do to protect biodiversity; some sponsoring of nature organisations takes place and some codes of conduct that include biodiversity related criteria are applied. The dominant activity now however is networking with primary and secondary stakeholders, discussing how biodiversity can be protected. 


\subsection{CSR Policy Becomes More Important}

Most selected companies consider CSR an issue for strategic policy. They have a small CSR unit or a sustainability manager working under the Corporate Affairs division. Compared to the regional companies in a previous research (Overbeek \& Harms, 2011), CSR units in both national and international companies less often fall directly under the communication unit. They develop a corporate strategy for CSR and indicators for measuring results. Together with the communication unit they report on sustainability through the annual reports. Biodiversity is a new theme, which is being worked on at the corporate level (Eneco, DSM, Shell, Ahold, \& KLM), while activities for nature management are more often the responsibility of the managers at the location (DSM, Heineken \& IKEA). The SMEs that rely on natural products do not have a defined CSR policy, but refer to the intrinsic attention to sustainability, which is not on paper, but interwoven into the company.

The development of a CSR policy by the companies is often justified by the explicit wish for a just, responsible image and the desire to be prepared for future social developments. Sometimes the interviewees of the selected companies go further and consider sustainability a 'growth driver' (Cono, DSM, \& Eneco). Companies also foresee the scarcity of raw materials for their production and their impact on deforestation. They use these factors as a motivation for CSR (Anova, Eneco, Heineken, IKEA, \& Shell).

Some interviewees represent a company that is poised to become a forerunner in sustainability to tap new markets by developing their own internal standards and practices (Anova, Cono, DSM, Eneco \& KLM). In this sense, at a strategic level their CSR approach has become more active. Other companies do not strive to open new markets with their CSR activities, but aim for a reputation as sustainable company in the eyes of its stakeholders (FrieslandCampina, Shell, Ahold, Heineken \& IKEA). Hence, their CSR approach may be considered as reactive. Some SME companies do not strive for a sustainable image and have no explicit CSR approach (Biohorma \& De Traay). Because of their origins in the trade of organic and natural produce, they already formed this image by nature of their business activities, which are perceived as sustainable. In this sense they may be considered as already having an active CSR approach.

\subsection{The Challenge to Fit in Biodiversity}

The interviewees were asked about their plans to protect biodiversity. Often, it is still not clear to them how to incorporate biodiversity in their business plans, even though they recognise the importance of biodiversity and ecosystems. From a policy life cycle perspective the plans and activities are at an initial stage; policies are formulated and action plans proposed, but relatively few concrete activities are carried out to protect biodiversity. Furthermore, the activities are restricted to certain issues, such a risk analysis of the own products (Ahold) and to enhance a sustainable biomass policy (Eneco). In terms of transition management, activities can be characterised as mainly strategic or tactical; the aim is to develop a sustainability vision and goals amongst a relatively small innovation network of forerunners and to gain societal support and attention for sustainability objectives by developing strategic coalitions with other firms and organisations (Loorbach et al., 2010).

The extent to which the interviewees are able to describe a relationship between their own company and biodiversity is quite limited. To the open question which relationships the interviewees perceive, they mention five different issues. The dependence on natural raw materials and the importance of the public opinion both to consumers, governments and NGOs are the most frequently cited relationships between companies and biodiversity. Other frequently mentioned issues were the location in vulnerable areas (nature) or creating a natural or partly natural area for the production and the production of certified/natural products by third parties via labels to consumers (such as MSC for sustainable fish, FSC for sustainable timber and biologic certificates) and businesses (such as ISO 26000). The dependence on ecosystem services - other than for the provision of raw materials - is mentioned the least. Where discussed, this dependency is not considered problematic and not in need of urgent improvement.

Often each interviewee mentioned more relationships. No relationship could be found between the relationships mentioned and the sustainability profile of the company. Hence, whether the CSR strategy is reactive, active or intended to become active, this has not been reflected in the management of biodiversity of ecosystems. Several reasons might be relevant, such as the limited description of the relation between the business activities and biodiversity management and the relevance or irrelevance of striving for a sustainable image concerning this.

\subsection{Activities to Manage Biodiversity}

Companies that have included biodiversity in their sustainability policy translate this issue in several activities. Four categories of activities may be distinguished (Table 2). 
Table 2. Overview of activities in the protection of biodiversity

\begin{tabular}{lll}
\hline & \multicolumn{1}{c}{ Activities } & \multicolumn{1}{c}{ Companies } \\
\hline Imposing & $\begin{array}{l}\text { Impose codes of conduct, including biodiversity } \\
\text { criteria (e.g. NTA8080, ASC), to suppliers }\end{array}$ & $\begin{array}{l}\text { Anova, Cono, DSM, Eneco, IKEA, } \\
\text { KLM, Shell }\end{array}$ \\
\hline Networking & $\begin{array}{l}\text { Involved in the development of sectoral } \\
\text { sustainability platforms and/or development of } \\
\text { sustainability standards (including biodiversity) }\end{array}$ & $\begin{array}{l}\text { Ahold, Anova, Cono, DSM, Eneco, } \\
\text { FrieslandCampina, IKEA, KLM, Shell }\end{array}$ \\
\hline Partnering & $\begin{array}{l}\text { Co-operation with NGOs on strategic level to } \\
\text { co-develop sustainability and/or biodiversity policies }\end{array}$ & $\begin{array}{l}\text { Ahold, Biohorma, Cono, DSM, Eneco, } \\
\text { FrieslandCampina, Heineken, IKEA, } \\
\text { KLM, Shell }\end{array}$ \\
\hline Sponsoring & $\begin{array}{l}\text { Financial support to (local or international) nature } \\
\text { organisations }\end{array}$ & Eneco, IKEA, KLM \\
\hline
\end{tabular}

Source: Compiled by the authors.

First, the companies may impose claims on suppliers. Those claims have been developed partly at the own initiative. An example is the fish trade company Anova, which has developed a code of conduct for fish farms, which has been used in the development of the ASC label (Aquaculture Stewardship Council). In the case of biofuels, companies have participated in the process of setting rules of conduct biodiversity (NTA8080) for a sustainable production (Eneco, Shell \& KLM). Cono has developed its own code of conduct for suppliers who are stimulated to take biodiversity protection measures.

Second, they may participate in sectorial consultative bodies and networks. Most companies are a member of consultative bodies such as the Dutch Sustainable Trade Initiative (IDH), Round Table on Sustainable Palm Oil (RTSPO), Round Table on Responsible Soy (RTRS), Platform Biodiversity Ecosystems and Economy (IUCN and VNO-NCW). In these networks, sector-wide initiatives to change production patterns, for example through the development of sustainability criteria and labels, have been taken. Participation in these networks means businesses can exert influence and are up to date on possible future criteria and regulation or self-regulation. Many of the large businesses interviewed are active in these networks.

Third, we see various partnerships with primary and secondary stakeholders. Several companies work as a partner with the nature organisation WWF (IKEA, KLM, FrieslandCampina \& Eneco). Shell branches work together with several nature organisations (IUCN, EarthWatch, Nature Conservancy \& Wetlands International). Biohorma supports the landscape organisation within the province of Gelderland financially, hires gardens in the nature area and organises the communication of the local products. Many interviewees work together with more NGOs than just nature organisations to direct their CSR policy. The stacking of environmental and social partnerships and memberships is illustrated by Eneco. The cooperation with NGOs, according to the companies, is not the result of social pressure. They recognise the importance of discussing together the instruments of governance for sustainability and want to keep a close watch on any developments in that area in order to be prepared for future laws and regulations (FrieslandCampina).

Fourth, the companies support local areas of natural beauty by sponsoring. The contribution to nature conservation aims to get more (local) goodwill and to strengthen the sustainable image of the company. The support of companies may include nature organisations responsible for nature conservation in local areas without having a direct sustainability relationship with the service or product of the company. Examples are KLM, which supports Landscape North Holland by protecting the black-tailed godwit in the Ilperveld nearby the Schiphol area, and Eneco, which supports WWF in its management of the Borneo's forests and orang utans. Contrary to this, IKEA supports the WWF for local projects in India and Russia that support sustainable production of commodities it uses, such as timber and cotton.

\subsection{Concern for Biodiversity in the Value Chain Governance}

The options that businesses have to involve other companies in the protection of biodiversity are influenced by the organisation of the value chain. Natural resources (such as palm oil, soy) are often traded in value chains characterised as 'market' (cf Gereffi et al., 2005) where relations between suppliers and buyer are weak as products go through various traders and middlemen. This makes it difficult to trace the origin of products. 
If additional requirements are wanted within these value chains, these have to be made through sector-wide standards such as those formulated in the Round Table of Responsible Soy. This can lead to the establishment of a different, certified, flow of products that meet the criteria agreed upon. Various companies are actively involved in the formulation of these criteria (Friesland Campina, Eneco \& DSM).

Companies that wish to set stronger standards on their own (Eneco \& CONO) can do so by imposing new standards, but this requires them to change value chain organisation and strengthen ties with dedicated suppliers. To put these criteria to work, buyers often cooperate with NGOs to support suppliers. Stronger ties with suppliers also serve another purpose, because they are a way to guarantee the supply of resources in a 'captive' value chain (Gereffi et al., 2005).

Finally, everyone foresees a role of the government in providing a framework with clear rules of the game that will reward forerunners and tries to involve laggards. This framework is seen as a general 'policy ' and not as detailed rules (Eneco, IKEA \& Anova) or restrictive regulations (Ahold). Subsequently, additional actions that the government may take are positive incentives and subsidies for 'icon projects' that show that something on a larger scale works (KLM) and that increase citizens' awareness of sustainable fisheries (Anova) and food wastage (Ahold).

\subsection{Obstacles to Take Biodiversity Protection a Step Further}

As this description of activities illustrates, all the interviewed companies undertake some activities related to biodiversity protection with an emphasis on networking activities. At this moment, the energy of the interviewed sustainability managers and directors is mostly spent on discussing biodiversity protection (generally as part of a broader sustainability agenda) and concrete actions are fewer in number.

A general feeling that the interviewees express is that the own organisation could spend more care on biodiversity. Until now, concrete activities focus mainly on the local protection and the local encouragement of nature. The challenges that companies face now is to develop a strategy and to ensure that biodiversity becomes topical within the whole organisation instead of only being a strategic policy issue. The first step is to monitor the current activities and the possible impacts on biodiversity. This strategy is similar to that of the economics of ecosystems and biodiversity (TEEB, 2010b) to assess business impacts and dependencies on biodiversity and ecosystems, including both direct and indirect linkages throughout the value chain, and to identify the business risks and opportunities associated with it.

The interviewees monitor their progress on sustainability in different ways, relying on for example Global Reporting Initiative (GRI) Guidelines or the FTSE4Good format. Biodiversity is not easy to grasp in a single index or performance indicator. Biodiversity is unique in each geographical location, is not interchangeable, and less easily estimated than $\mathrm{CO}_{2}$. This is a 'problem' for internal and external alignment. Companies that have the internal ambition to measure their impact on biodiversity struggle to realise this as well. In the interviews, they could not make clear how biodiversity is measured (such as Ahold with its brand products). Many companies prepare 'codes of conduct' for the suppliers of raw materials or products that it sells to customers. This is accompanied by internal and external audits where guidelines such as ISO14001 are used. In the absence of a single undisputed indicator for biodiversity, inclusion of this issue is problematic.

Big retailers such as IKEA and Ahold argue that the secured supply of sustainable products and certified products is important. This requires not only certification, but also sufficient volumes of sustainable products. IKEA in particular indicates that for its purchase volumes the availability of sustainable timber is a problem.

\section{Discussion about Opportunities for More Contribution}

The results from the interviews with the sustainability representatives show that their business activities can be characterised as mainly strategic or tactical; the aim is to develop a sustainability vision and to gain societal support and attention for sustainability objectives. Many companies use a reactive CSR approach. Few approach biodiversity pro-actively, leading the other companies by the development of for example own policies, indicators and codes of conduct. The motivation comes mainly from the experienced dependence of a deficient supply of raw materials and the wish to avoid negative publicity. The results from the interviews with sustainability representatives are in line with the survey data on sustainability, in which companies still take a fragmented, reactive approach rather than treating sustainability as an issue with a direct impact on business results (McKinsey, 2011). This may be because the relationship between business activities and biodiversity is still hardly elaborated and difficult to grasp. Result-oriented actions occur mainly through certification of products and the setting of requirements to suppliers via behavioural rules. 


\subsection{Companies Can Achieve More Goals}

Many interviewees work for companies that function as a 'lead firm' in their production chain and play an important role in securing raw materials and markets. Although the internal interest of companies in biodiversity is still limited, they spend considerable attention to the assessment of external parties about their sustainability performance. To increase their accountability to stakeholders on environmental and social issues, they publish sustainability reports in which they express their commitment and outline activities undertaken to prevent environmental pollution, human rights violations and other 'externalities' of international trade and production (Kolk, 2011). These assessments can produce a higher status and improve the reputation of the company. The Dow Jones Sustainability Index (DJSI) works as a benchmark for companies wanting to score better than others in their branch and sector. In more specific reports as the Global Reporting Initiative (GRI), nature and biodiversity are included in the evaluation criteria, but often not yet filled in as such. The findings of GRI reporting show that large companies do this much more often than smaller companies. As a result any large companies that are not already reporting on corporate responsibility will soon run the risk of being viewed as less transparent than their peers (KPMG, 2011).

One of the main barriers that prevents investment in biodiversity is the lack of information, the lack of insight how to collect useful information and the uncertainty about the impact of activities. Companies do not produce sufficient and detailed information on their impact and dependencies on biodiversity and ecosystem services. Business risks arising from a company's dependence and impact on ecosystem services have to be mapped better (TEEB, 2010b). NGOs expect more urgency from financial market leaders to identify business impacts and dependencies on biodiversity and ecosystems, because they are going to put more pressure to access the risks of business activities for nature protection and biodiversity. Transparency on these subjects will help companies and investors to produce sound business planning (Lambooy \& Levashova, 2011). Furthermore, results-based appointments can be included and evaluated more often instead of just only process-based appointments. This will require a clearer vision on whether a transition towards a sustainable biodiversity will be considered successful or not. Until now, due to the predevelopment stage of the transition, there have been no clear visions.

By developing a clearer vision, it might be relevant to elaborate the relationship between the type of sectors the companies are active in and their challenges to protect biodiversity. Borrowing from Bosman et al. (2013) we may distinguish three types of relationships:

(1) Do their activities strengthen biodiversity? For those companies it will be relevant if their investments will be rewarded. Thus if there will be a market - rewarded by customers or made by the government - created to pay more for their products. Examples from our selected companies are Biohorma and De Traay Products.

(2) Are their activities dependent of biodiversity and do they have an impact on it? For those companies it will be relevant to find a balance between their (a) biotic production and the regeneration of the ecosystems. Thus if they will produce without exhausting the ecosystem. Examples from our selected companies are Eneco, Anova and Cono Kaasmakers that aim for a positive or neutral balance and Ahold, FrieslandCampina, Ikea and Heineken that aim to decrease their negative balance.

(3) Do their activities have an impact on biodiversity due to their location? Those companies are not dependent of biodiversity, but mainly have an impact on it. They process mainly abiotic resources. For those companies it will be relevant to reduce their impact as much as possible and to compensate their loss of biodiversity, for example through mechanisms such as "no net loss of biodiversity". Examples from our selected companies are DSM, KLM and Shell.

Companies can also work with biodiversity within their organisation and may thus become more active. During the interviews the importance of sustainability counts mainly within institutional forms, while there also good practices imaginable by experimenting with practical solutions.

\subsection{NGOs as Incentive and More Public Ambition}

Despite more attention to experiment with practical solutions, the real challenge is to increase the urgency to find more solutions to reduce the negative impacts on biodiversity and ecosystems and to develop business models with more added social and environmental value.

International NGOs may bring the urgency to protect biodiversity higher on the agenda of companies, due to their knowledge of geographic areas where raw materials are extracted and their relationships with relevant local stakeholders. Collaborating with NGOs offers companies the advantage of a reliable reputation that increases the demand for sustainable products among their customers. Conversely, NGOs expect attention for the activities of 
companies in areas with natural values. They can use their international contacts with their sister NGOs to point companies to the impact of their biodiversity activities in the countries concerned.

At the same time, NGOs may keep companies alerted to their sustainability performance and through consumers may influence the assessment of their products and services. This requires more focus on the main production chains, the preservation of biodiversity and visualising the international relationship between sustainable production and consumption. The WWF approach to zoom in on companies in production chains with a strong relationship with biodiversity may enhance this approach. For a more sustainable consumption, however, attention is also required to increase the awareness of global citizens. This can be done by pointing out to consumers the impacts of their behaviour elsewhere in the world and the measures they can take to reduce their impact (ecological and water footprints etc.).

Both the interviewed representatives of companies and NGOs want a stronger government with political ambition and leadership to achieve more sustainability and more frameworks to stimulate sustainable production and consumption. It is important to create more awareness for new markets among consumers and producers, whereby the government can choose strategies ranging from self-initiation to strengthening self-regulation in the market (Vermeulen et al., 2011). At the same time, the government can take the initiative to commercialise products and services for its own purchase and setting standards through legislation. Furthermore, subsidies and regulations can influence the use of biodiversity by deploying positive stimuli to forerunners, paying for ecosystem services (REDD +, product certification) and by stimulating transparency on environmental costs. However, regulations can be achieved only partially by a national government, because the production processes of the international companies extend beyond the Netherlands.

\section{Acknowledgements}

This paper is based on a WOt project 'Socialization of nature and landscape' (Overbeek, Harms \& Van den Burg 2011) conducted for the PBL Netherlands Environmental Assessment Agency and funded by the Ministry of Economic Affairs.

\section{References}

Bosman, R., Loorbach, D., Van Raak, R., Wijsman, K., Bor, A., \& Van Leenders, C. (2013). Bedrijven en Biodiversiteit: Transitie-perspectief vanuit de Community of Practice Bedrijven en Biodiversiteit. [Businesses and Biodiversity: Transition perspective from the Community of Practise Businesses and Biodiversity] Rotterdam: Dutch Research Institute For Transitions (DRIFT). Retrieved July 22, 2013, from www.drift.eur.nl/wp-content/uploads/2013/07/Transitie-perspectief-CoP-Bedrijven-en-Biodiversiteit.pdf

Convention on Biological Diversity. (1992). Text of the convention on biological diversity. Retrieved January 3, 2013, from www.cbd.int/convention/convention.shtml

De Tienne, K. B., \& Lewis, L. W. (2005). The pragmatic and ethical barriers to corporate social responsibility disclosure: The Nike case. Journal of Business Ethics, 60(4), 359-376. http://dx.doi.org/10.1007/s10551-005-0869-x

Gale, F. P. (2000). Economic specialisation versus ecological diversification: the trade policy implications of taking the ecosystem approach seriously. Ecological Economics, 34, 285-292. http://dx.doi.org/10.1016/S0921-8009(00)00181-6

Gereffi, G., Humphrey, J., \& Sturgeon, T. (2005). The governance of global value chains. Review of International Political Economy, 12(1), 78-104. http://dx.doi.org/10.1080/09692290500049805

Jonker, J., \& Nijhof, A. (2006). Looking through the eyes of others: assessing mutual expectations and experiences in order to shape dialogue and collaboration between businesses and NGOs with respect to CSR. Corporate Governance, 14(5), 456-466. http://dx.doi.org/10.1111/j.1467-8683.2006.00518.x

Kolk, A. (2011). The evolution of sustainability reporting by international firms. Fiducie 18, 14-19. Retrieved July 23, 2013, from www.fiducie.nl/files/nlfsa/file/fiducie/1027-1071_FSA-Fiducie-1102-02-1101311235-LOWRES.pdf

Kolk, A., \& Van Tulder, R. (2010). International business, corporate social responsibility and sustainable development. International Business Review, 19, 119-128. http://dx.doi.org/10.1016/j.ibusrev.2009.12.003

KPMG. (2011). KPMG International Survey of Corporate responsibility Reporting 2011. Retrieved January 3 , 2013, from www.kpmg.com/PT/pt/IssuesAndInsights/Documents/corporate-responsibility2011.pdf

Kumar, M., \& Kumar, P. (2008). Valuation of the ecosystem services: A psycho-cultural perspective. Ecological 
Economics, 64(4), 808-819. http://dx.doi.org/10.1016/j.ecolecon.2007.05.008

Lambooy, T., \& Levashova, Y. (2011). Opportunities and challenges for private sector entrepreneurship and investment in biodiversity, ecosystem services and nature conservation. International Journal of Biodiversity Science, Ecosystem Services \& Management, 7(4), 301-318. http://dx.doi.org/10.1080/21513732.2011.629632

Lim, S. J., \& Phillips, J. (2008). Embedding CSR values: The global footwear industry's evolving governance structure. Journal of Business Ethics, 81(1), 143-156. http://dx.doi.org/10.1007/s10551-007-9485-2

Loorbach, D., Van Bakel, J. C., Whiteman, G., \& Rotmans, J. (2010). Business Strategies for Transitions Towards Sustainable Systems. Business Strategy and the Environment, 19(2), 133-146. http://dx.doi.org/10.1002/bse.645

Loorbach, D., \& Wijsman, K. (2013). Business transition management: exploring a new role for business in sustainability transitions. Journal of Cleaner Production, 45, 20-28. http://dx.doi.org/10.1016/j.jclepro.2012.11.002

Maignan, I., \& Ralston, D. A. (2002). Corporate Social Responsibility in Europe and the U.S.: Insights from Businesses' Self-Presentations? Journal of International Business Studies, 33(3), 497-514. http://dx.doi.org/10.1057/palgrave.jibs.8491028

McKinsey. (2011). The Business of Sustainability. Retrieved July 1, 2013, from http://download.mckinseyquarterly.com/the_business_of_sustainability.pdf

Millennium Ecosystems Assessment. (2003). Ecosystems and Human Well-Being. Washington DC: Island Press. Retrieved January 3, 2013, from http://pdf.wri.org/ecosystems_human_wellbeing.pdf

Overbeek, G., \& Harms B. (2011). From sponsor to partner: NGO-business alliances that support nature conservation in the Netherlands. Journal of Integrative Environmental Sciences, 8(4), 253-266. http://dx.doi.org/10.1080/1943815X.2011.608071

Overbeek, M. M. M., Harms, B., \& Van den Burg S. W. K. (2012). Internationale bedrijven duurzaam aan de slag met natuur en biodiversiteit. [International companies get active with nature and biodiversity]. Voorstudie bij de Balans van de leefomgeving 2012. Wageningen: WOt Natuur \& Milieu, WOt-werkdocument 274. Retrieved January 3, 2013, from http://content.alterra.wur.nl/Webdocs/WOT/Werkdocumenten/WOTwerkdocument_274.pdf

Porter, M. E., \& Kramer, M. R. (2006). Strategy and Society: The Link Between Competitive Advantage and Corporate Social Responsibility. Harvard Business Review, 78-92. Retrieved January 3, 2013, from http://www.fsg.org/tabid/191/ArticleId/46/Default.aspx?srpush=true

PWC. (2010). 13th Annual Global CEO Survey 2010. PriceWaterhouse \& Coopers. Retrieved January 3, 2013, from http://www.pwc.com/gx/en/ceo-survey/index.jhtml?WT.ac=vt-ceosurvey

Quinn, F. J. (1997). What's the buzz? Logistics Management, 36(2), 43-47.

Rockström, J., Steffen, W., Noone. K., Persson, Å., Chapin, F., Lambin, E. F., ... Foley, J. A. (2009). Planetary boundaries: exploring the safe operating space for humanity. Ecology and Society, 14(2), 32. Retrieved January 3, 2013, from http://www.ecologyandsociety.org/vol14/iss2/art32/

Schouten, G., \& Glasbergen, P. (2011). Creating legitimacy in global private governance: The case of the Roundtable on Sustainable Palm Oil. Ecological Economics, 70, 1891-1899. http://dx.doi.org/10.1016/j.ecolecon.2011.03.012

Taskforce Biodiversity and Natural Resources. (2011). Retrieved July 23, 2013, from http://en.biodiversiteit.nl/samenwerking-voor-biodiversiteit/taskforce-biodiversiteit-natuurlijke-hulpbronnen

TEEB. (2010a). The Economics of Ecosystems and Biodiversity for National and International Policy Makers. Executive Summary. Retrieved October 3, 2012, from www.teebweb.org

TEEB. (2010b). The Economics of Ecosystems and Biodiversity. Report for Businesses. Executive Summary. Retrieved October 3, 2012, from www.teebweb.org

Van Huijstee, M. (2010). Business and NGOs in interaction. A quest for corporate social responsibility [thesis]. Utrecht: Nederlandse Geografische Studies 393.

Van Tulder, R., Bleijenbergh, M., Danse, M., Wiersinga, R., \& Torpe, M. (2009). CSR business models and change trajectories in the retail industry - a Dynamic Benchmark Exercise (1995-2007), RSM Erasmus 
University and LEI-Wageningen UR, Report 2009-075. Retrieved July 1, 2013, from http://www.lei.dlo.nl/publicaties/PDF/2009/2009-075.pdf

Van Tulder, R., \& Van der Zwart, A. (2006). International Business-Society Management - Linking corporate responsibility and globalization. London and New York: Routledge.

Vermeulen, W., Kok, M., \& Van Oorschot, M. (2011). Reflectie op rol overheid bij verduurzaming productketens. [Reflection on government role in sustainable product chains.] Milieu, 2, 17-21. Retrieved October 3, 2012, from

http://www.pbl.nl/sites/default/files/cms/publicaties/VVM\%20Doss\%202011-2\%20art1_high\%20res.pdf

\section{Copyrights}

Copyright for this article is retained by the author(s), with first publication rights granted to the journal.

This is an open-access article distributed under the terms and conditions of the Creative Commons Attribution license (http://creativecommons.org/licenses/by/3.0/). 